\title{
A BIBLIOGRAPHY OF JOHN HUTCHINSON
}

\author{
by
}

P. J. BISHOP*

1. Society of Arts. 29 May 1844.-W. H. Bodkin, Esq., M.P., V.P., in the chair. Lancet, 1844, i: 390-391 (15 June).

Notes: "The Secretary read a paper by Mr. Hutchinson on his Pneumatic Apparatus for Valuing the Respiratory Powers, which was illustrated by about twenty large diagrams and tables. The apparatus was also placed on the table."

At first sight it would appear that Hutchinson himself was not present at the above meeting, as his paper was read by the Secretary. But after giving a description of the "Breathing Machine", for measuring "volume", and the "Inspirator", for measuring "power", and giving Hutchinson's findings in nearly 1,200 observations, the report goes on to say: "Several persons, including fire-brigade men, wrestlers, gentlemen, and particularly Robinson, the well-made dwarf, thirty-six years of age, and three feet nine inches high, were subjected to the trial of Mr. Hutchinson's apparatus, under his immediate superintendance. ..."

It is then clear that Hutchinson himself must have been present at the meeting. The above short report in the Lancet would appear to be the first appearance in print of Hutchinson's work with the spirometer. It is interesting that he chose to make his first communication to this famous old Society (founded in 1754), but it is clear from its histories and its Transactions, that it served as a forum for the presentation of papers on a wide variety of topics, some of which were concerned with apparatus of scientific or medical interest; as well as matters of public health and sanitation. In view of Hutchinson's known interest in mechanical engineering his choice can be readily understood. In addition, one has to remember that there were relatively few general medical societies in London at the time, and Hutchinson, with his mechanical turn of mind, would have been attracted to the Society, with its long tradition of "encouraging" useful inventions and their application.

2. 'Neue pneumatischer Apparat zur Prüfung des Respirations-vermogens', Neue Notizen aus dem Gebiete der Natur und Heilkunde, von L. F. Froriep und S. Froriep, Weimar, 1844, 31: columns 182-184 (No. 12 of vol. 31, no. 672-September).

Notes: This important German periodical contained an abstract of Hutchinson's communication to the Society of Arts (item No. 1 above).

3. Medical Societies. Statistical Society of London. Monday, 17 June 1844. Lieutenant-Colonel Sykes, V.P., in the Chair, 'Lecture in vital statistics, embracing

'P. J. Bishop, The Library, Cardiothoracic Institute, Brompton, London SW3 6HP. 


\section{A bibliography of John Hutchinson}

an account of a new instrument for detecting the presence of disease in the system'. By John Hutchinson, Esq., M.R.C.S. Lancet, 1844, i: 567-570 (27 July); 594-597 (3 August).

Notes: The above two-part paper is really a report of Hutchinson's lecture delivered before the Statistical Society of London. It begins: "The Society's rooms were much crowded this evening, chiefly with members of the medical profession, to hear a lecture by Mr. Hutchinson, and to witness experiments, on living individuals, with his pneumatic apparatus, or, as the inventor terms it, the 'spirometer', or 'breath-meter'." Hutchinson's lecture was illustrated by diagrams, some of which were passed round among his audience, and in addition to reporting his results, based upon his examination of 1,200 people, he included a practical demonstration of the spirometer. It is clear that his lecture made a considerable impact on his audience, and in the discussion which ensued a Mr. Fisher said: "he had in his lifetime examined 140,000 men for public duty, and had he possessed such an instrument as Mr. Hutchinson's, it would have saved him many times from selecting men who afterwards turned out not eligible for duty". The report ended by saying: "The discussion was kept up until an unusually late hour, when the President proposed a vote of thanks to Mr. Hutchinson for his highly interesting and labourious researches, which was warmly acceded to."

Hutchinson was an early Fellow of the Statistical Society of London (founded in 1838) having been elected in 1842: his sponsor was William Farr.

4. 'Contributions to vital statistics, obtained by means of a pneumatic apparatus for valuing the respiratory powers in relation to health'. By John Hutchinson, Esq., Surgeon, F.S.S. (Read before the Statistical Society of London, 17 June 1844), Journal of the Statistical Society (Quarterly Journal of the Statistical Society), 1844, 7: 193-212 (September).

Notes: The above is the full text of Hutchinson's paper read before the Society. It reported on his examination of 1,151 people, and would appear to be his first full paper, rather than a report of a meeting. It included his tables, but no illustration of the spirometer.

\section{Contributions . . ., 1844. London, 1844, 20pp., 6 diagrams, 8 vo.}

Notes: This is a word-for-word reprint of item No. 4. I believe it was issued without covers. Copies are to be found in the Thane Library, University College London; the University of London Library; and the National Library of Medicine, Bethesda, Md., U.S.A.

6. No. XXXIV. 'On a pneumatic apparatus for valuing the respiratory powers with relation to health'. By John Hutchinson, F.S.S. 29 May 1844. W. H. Bodkin, Esq., M.P., V.P. in the chair. Abstract. Transactions of the Society for the Encouragement of Arts, Manufactures, and Commerce, London, 1845, 55: 199-203.

Notes: This volume published in 1845, contained the papers presented during the sessions of 1843-44. A footnote to page 199 refers to Hutchinson's later paper read before the Statistical Society of London (item No. 4 above). Item 6 contained a description of Hutchinson's apparatus-rather than an account of a 


\section{P. J. Bishop}

meeting-as found in item 1 above.

7. 'On the capacity of the lungs, and on the respiratory functions, with a view of establishing a precise and easy method of detecting disease by the spirometer'. By John Hutchinson, Surgeon. Communicated by George Cursham, M.D., one of the Secretaries of the Society. Received January 22nd-Read 28 April 1846. MedicoChirurgical Transactions, published by the Royal Medical and Chirurgical Society of London, 1846, 29 : 137-252.

Notes: The above lengthy paper, or rather monograph, illustrated by diagrams and tables, which included illustrations of the spirometer, contained the most detailed account of Hutchinson's work which had appeared up to that time. It reported his observations of 2,130 persons from all walks of life: quite literally from dwarfs to draymen and from princes of the blood to pugilists. The communication was made by George Cursham, who was the following year appointed Assistant-Physician to the recently opened Brompton Hospital. Hutchinson concluded: "The matter of this communication is founded upon a vast number of facts-immutable truths, which are infinitely beyond my comprehension. The deductions, however, which I have ventured to draw therefrom, I wish to advance with modesty, because time, with its mutations, may so unfold science as to crush these deductions, and demonstrate them as unsound. Nevertheless, the facts themselves can never alter, nor deviate in their bearing upon respiration-one of the most important functions in animal economy."

I have never seen reprints of the above, and to the best of my knowledge it was not the custom of the Transactions to provide them at the time.

8. Transactions of Learned Societies. Royal Medical and Chirurgical Society. Meeting of 28 April 1846. Dr. Chambers, ... President, in the Chair. 'On the capacity of the lungs and on respiratory movements, with a view of establishing a precise and easy method of detecting disease by the spirometer'. By John Hutchinson, Esq.: presented by Dr. Cursham. Medical Times: A Journal of English and Foreign Medicine, and Miscellany of Medical Affairs, London, 1846, 14: 106-108 (9 May, No. 345).

Notes: The above journal contained a good account of the meetings and discussion.

9. Royal Medical and Chirurgical Society. 28 April-Dr. Burrows in the Chair. 'On the capacity of the lungs, and on the respiratory movements, with a view of establishing a precise and easy method of detecting disease by the spirometer'. By John Hutchinson, Esq. (Presented by Dr. Cursham.) Lancet, 1846, i: 630-632 (6 June).

Notes: The Lancet contained a good account of the meeting, and mentioned some of the discussants by name. Mention was also made of one of the dwarfs examined by Hutchinson: Don Francisco, height under thirty inches-and a Mr. Randall, who was seven feet high.

10. Royal Medical and Chirurgical Society. 28 April-Dr. Burrows in the Chair. 


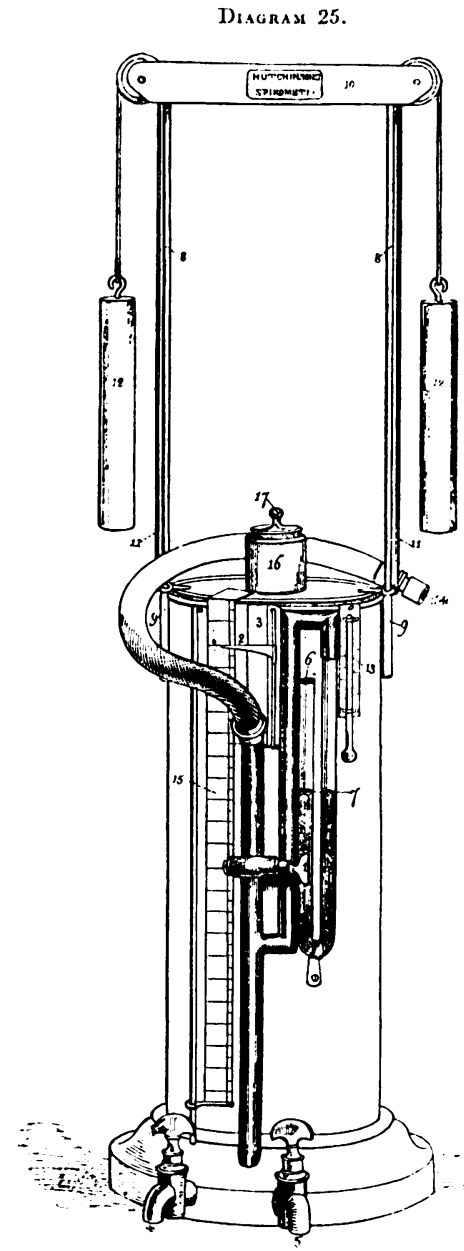

Figure 1.

Diagram illustrating the spirometer. From Med.-Chir. Trans., 1846, 29: 234. 


\section{Diagram 26.}

Position of the body in filling the chest before breathing into the Spirometer.

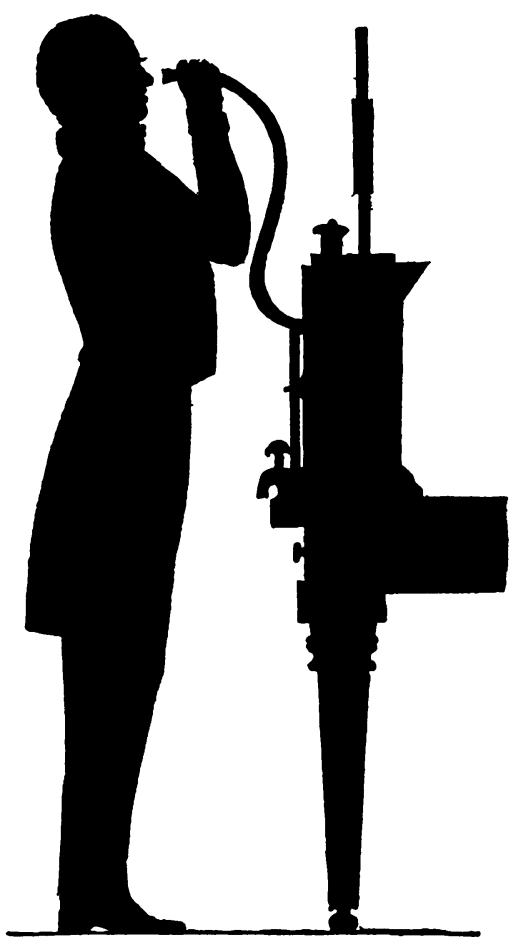

To measure the vital capacity of the lungs.

Figure 2.

One of the silhouettes from Hutchinson's 1846 paper, ibid., p. 236. 


\section{A bibliography of John Hutchinson}

'On the capacity of the lungs, and on the respiratory movements, with a view of establishing a precise and easy method of detecting disease by the spirometer'. By John Hutchinson. (Presented by Dr. Cursham.) Dublin Medical Press, 1846, 15: 386-389 (24 June, No. 390).

Notes: This was taken from item No. 9 above.

11. 'Études sur les phénomènes mécaniques de la respiration et sur la capacité pulmonaire; nouveau moyen de diagnostic dans les maladies de poitrine (1)'. Par le Dr. John Hutchinson. Archives générales de Médecine, 4th series, 1847, 13: 204-220 (February).

Notes: The footnote states that this extract was made from the Med.Chir. Trans., of 1846. It refers to the length of the original, and says it will confine itself to giving a simple extract, conserving as much as possible the character and form of the original.

12. XXXVIII. Proceedings of Learned Societies. Royal Society. 17 June 1847. 'Researches on the function of the intercostal muscles and on the respiratory movements, with some remarks on muscular power in man'. By John Hutchinson, M.R.C.S. Communicated by Sir Benjamin Brodie, ...., The London, Edinburgh, and Dublin Philosophical Magazine and Journal of Science, 3rd series, 1847, 31: 222-224 (September).

Notes: This begins: "The object of this paper is to demonstrate by models and dissections the action of the intercostal muscles".

13. XVIII. 'Uber die Function der Intercostalmuskeln und die Respirationsbewegungen des Menschen'. Neue Notizen aus dem Gebiete der Natur und Heilkunde dritter Reihe, von Robert Froriep und M. J. Schleiden, 1847, 4: columns 149-150. (No. 1 of vol. 4. no. 67-September).

Notes: This German abstract was based upon the report in the Philosophical Magazine of 1847 (item No. 12 above).

14. 'Studien über die mecanische Phänomene der Athmungsprocesses und der Lungencapacität; ein neues diagnostiches Mittel in Brustkrankheiten'. Von John Hutchinson. Archiv für physiologische und pathologische Chemie und Mikroskopie, redigirt von J. F. Heller, Wien, 1847, 4: 169-180.

Notes: Heller's Archiv published this long extract from the Med. Chir. Trans., of 1846, and also gave the reference to the extract in the Archs. gén. Méd., of Paris (item No. 11 above).

15. XII. 'On the capacity of the lungs, and on the respiratory functions, with a view to establishing a precise and easy method of detecting disease by the spirometer'; by John Hutchinson. The British and Foreign Medical Review or Quarterly Journal of Practical Medicine and Surgery, 1847, 24: 327-328 (July-October) (October).

Notes: This extract in this important journal edited by John (later Sir John) Forbes, begins: "It is quite impossible to give anything like a full analysis of this most 


\section{P. J. Bishop}

elaborate production, but we have no hesitation in recording our deliberate opinion, that it forms one of the most valuable contributions to physiological science that we have met with for some time. In all future investigations into the phenomena of the respiratory processes, the name of Mr. Hutchinson must receive honorable notice."

16. Hutchinson's M.D. Thesis, Giessen, 1848. 'On the capacity of the lungs and on the respiratory functions [?]'

Notes: From correspondence I have had with the Librarian of the University of Giessen, it would appear that the copy of Hutchinson's dissertation, formerly in their possession, was lost in the bombing in World War II (in 1944). There are some grounds for thinking that the Giessen M.D., could be obtained fairly easily at the time (see an article in Rostrum, July, 1974, p. 17), but it may well have been that Hutchinson submitted a written work-I suspect a copy or version of his 1846 monograph (item No. 7 above) as part of the requirements for obtaining the doctorate in absentia. The Dekanatsbuch of the Faculty of Medicine records that the M.D., was conferred on 14 March 1848, but, contrary to custom, the work submitted was not published.

17(a). 'Ventilation in general. The atmosphere-heat-expansion-communication, and radiation, in relation to public health'. By John Hutchinson, M.D. Journal of Public Health \& Monthly Record of Sanitary Improvement, published under the sanction of the Metropolitan Health of Towns Association, 1848, 1: 231-234 (published July 1848).

Notes: This journal, which became the organ of the Health of Towns Association, was edited by John Sutherland and Hector Gavin. Only two volumes were published (1848-49). The above paper was the first in a series of twelve contributed by Hutchinson, on all aspects of ventilation, between July 1848 and June 1849 . The papers seem to me to be of such significance in revealing Hutchinson's extensive knowledge of a subject then engaging the attention of so many medical men and sanitary reformers, that I give here details of the sub-titles of all twelve parts (17a-m).

17(b). No. II. Reflection, absorption, latent heat, specific gravity, and composition of the atmosphere. Ibid., 1848, 1: 263-265.

17(c) No. III. Of the function of respiration-air poisoned by in-door circumstances, illustrated by facts. Ibid., 1848, 1: 295-298 (dated August).

17(d). No. IV. Of air poisoned by out-door circumstances, illustrated by facts. Ibid., 1848, 1: 311-315 (14 September).

17(e). Correspondence. Letter from Hutchinson in reply to a letter from a Dr. James Stark, who had objected to a remark Hutchinson had made on p. 234: "that radiation does not appear to be affected by colour". At this time Hutchinson was living at 105, Milton Street, Dorset Square, London. Ibid., 1848, $1: 331$. 


\section{A bibliography of John Hutchinson}

17(f). No. V. Of air poisoned by out-door circumstances, illustrated by facts(concluded). Ibid., 1849, 2: 3-7 (16 October 1848).

71(g). No. VI. On the art of moving air, or ventilating-physical ventilators. Ibid., 1849, 2: 29-32 (15 November 1848).

Notes: The above paper included a description of Dr. Neil Arnott's pump used to supply forced warm air to the wards of the Hospital for Consumption and Diseases of the Chest at Brompton.

17(h). No. VII. Of physical ventilators (continued)-the fanner, the screw, and steam. Of chemical ventilators-rarefaction by heat or combustion. Ibid., 1849, 2: 57-61 (13 December 1848).

17 (i) No. VIII. Of chemical ventilators-rarefaction by heat or combustion(continued). Ibid., 1849, 2: 85-88 (17 January 1849).

Notes: From this paper it would appear that two old Chelsea pensioners laboured at the pump described earlier by Hutchinson on page 32, but he tells us that "a time came when this Hospital for Consumption substituted a steam-engine for these two old veterans".

17(j) No. IX. Of the quantity of air necessary for our well-being. Ibid., 1849, 2: 113-117 (20 February 1849).

17(k). No. X. Of ingress and egress apertures for air-or external and internal valvular openings for air in public or private habitations. Ibid., 1849, 2: 141-145 (20 March 1849).

17(1). No. XI. Of ingress and egress openings of private rooms-of the application of a sure moving power for ventilating any building-remarks-precautions-why the current in ventilation should be modified. Ibid., 1849, 2: 169-175 (April 1849).

17(m). No. XII. Of quality of air for ventilation. Ibid., 1849, 2: 225-229 (June 1849).

Notes: This final article, like all its predecessors, is extremely interesting. In it Hutchinson touches upon the question: "That foreign matter does exist in the air around us, not visibly, but which may affect our health" (p. 27). One can easily imagine how this series of articles, full of interesting facts and observations, must have helped to establish Hutchinson's reputation. Following on from his work with the spirometer, they explain why his obituary notices, particularly the one in the Medical Times and Gazette (item No. 33) below, were so eulogistic in tone.

18. Von der Capacität der Lungen und von den Athmungs-Functionen, mit Hinblick auf die Begründung einer genauen und leichten Methode, Krankheiten der Lungen durch das Spirometer zu entdecken. Von John Hutchinson. Aus der Englischen übersetz 


\section{P. J. Bishop}

und mit Anmerkung versehn von Dr. Samosch. Mit zahlreichen in den Text eingedruckten Holzschnitten. Braunschweig, Friedrich Vieweg und Sohn, 1849, 8vo, pp. iv, 131.

Notes: This item, which I have every reason to believe is a very rare one, is a full German translation of Hutchinson's monograph of 1846 (item No. 7 above). As the title-page indicates, the work contains some notes and annotations from the translator, Dr. Salomon Samosch (1817-1887). It is quite clear from Samosch's preface, dated Breslau, 5 January 1848, that the translation was made because of the obvious importance of the work. Reference is also made to the spirometer's influence on examination for life assurance purposes. Samosch's post-script is concerned mainly with relative mortality statistics of pulmonary tuberculosis in different cities. His notes are clearly signed and identifiable. Apart from the above translation, the only publication by him is listed in the Index Catalogue, etc. I am indebted to Dr. John B. Blake, Chief, History of Medicine Division, National Library of Medicine, for providing me with a photocopy of this work.

\section{8(a). J. Hutchinson, letter (untitled), Lancet, 1849, i: 107 (27 January).}

Notes: This letter from Hutchinson (now described as M.D.) was written from his house at Milton Street. It is concerned with the remuneration of medical referees for life offices. Hutchinson himself does not refer to his association with the Britannia Life Assurance Society, but an editorial footnote does.

19. Reports from Committees: Fourteen Volumes. (1.) Accidents in Coal Mines. Session 1 February to 1 August 1849. Vol. VII, 1849, pp. 140-164; 602-604 (printed 26 July 1849); 613. Report from the Select Committee of the House of Lords on Accidents in Coal Mines; together with the Minutes of Evidence, Appendices, Plans, and Index.

Notes: Pages 140-164 (numbered questions 1409-1556) contain the questions put to Hutchinson and his answers. They reveal that he was physician to an insurance company; that he had fifteen years' experience of coal mines, which he had personally visited between two and three hundred times. His evidence was mainly concerned with problems of ventilation, firedamp, and the risk of mine explosion. He also conducted some experiments with a candle. Reference was made to collieries at Springwell, Jarrow, and Haswell. It is also clear that Hutchinson's evidence had already been communicated to Sir George Grey of the Home Office, and his recommendations had been laid before the Secretary of State, Sir George De la Beche. Pages 602-604 (Appendix D) contain a copy of a letter from John Hutchinson, Esq., M.D., to the Right Honourable Lord Wharncliffe, President of the Committee of Lords on coal mines explosions. This letter is concerned with fire-damp, and "of the existence of charcoal or black matter in the lungs of miners"; "of the depth of a mine upon the health of a miner"; and in his observations on "charcoal or black matter in the lungs", he refers to the published work of Prof. Graham, Dr. William Thompson, and Prof. Schönlein. It is clear from Hutchinson's evidence that he had a profound and extensive knowledge of mining matters. 


\section{A bibliography of John Hutchinson}

20(a). Diagnosis and treatment of pulmonary consumption. By John Hutchinson, M.D. Assistant Physician to the Hospital for Consumption and Diseases of the Chest. Medical Times, new series, 1850, 1: 141-142 (10 August).

20(b). No. II. Of the second symptom of pulmonary consumption. Ibid., 1850, 1: 194-195 (24 August).

20(c). No. III Abnormal breathing-sounds. Ibid., 1850, 1: 250-253 (7 September).

20(d). No. IV. Treatment. Ibid., 1851, 2: 5-7 (4 January).

Notes: The above four-part paper (20a-d), written when Hutchinson was living at Milton Street, is of particular interest. Although the words "to be continued" appear at the end of the fourth part, it does not seem that any more parts were published. The paper reflects something of Hutchinson's rather refreshing-and for the times, rather informal-style of writing.

21. Reports of Societies. Medical Society of London. F. Hird, Esq., Vice-President, in the Chair. Medical Times, 1851, 2: 463-464 (26 April).

Notes: This shows that Hutchinson presented his paper before the Medical Society of London, although it does not give a date. It was probably a shorter version of his four-part paper (item No. 20a-d above).

22. 7. 'Researches on the Function of the Intercostal Muscles and on the Respiratory Movements, with some remarks on Muscular Power in Man'. By John Hutchinson, M.R.C.S., Communicated by Sir Benjamin Brodie. Abstracts of the Papers Communicated to the Royal Society of London, from 1843 to 1850 inclusive. 1851, 5: 1843 to 1850 , pp. 691-693.

Notes: The Abstracts, later known as the Proceedings of the Royal Society of London, published this account of a meeting of 17 June 1847, which was chaired by the President, the Marquess of Northampton. It did not, however, appear until 1851 (see also item No. 12 above).

23. Same title as item No. 22 above. Abstracts of the Papers Communicated to the Royal Society of London, 1851, 7: 760-761.

Notes: This is a short five-line reference to a meeting of 25 May 1848, which was in turn an abridgement of the former communication of 17 June 1847.

24. Art. 16. 'Tabular view of the symptoms of phthisis'. By Dr. John Hutchinson. (Medical Times, August 1850). The Half-Yearly Abstract of the Medical Sciences, etc. edited by W. H. Ranking, 1851, 12: 43 (July-September).

Notes: This famous abstracting journal merely reproduced a table from Hutchinson's paper (item No. 20c above).

25. 'Thorax'. In The cyclopaedia of anatomy and physiology, edited by R. B. Todd, London, Longmans, 1852, vol. 4, PLA-WRI, pp. 1016-1017. 


\section{P. J. Bishop}

Notes: Hutchinson's very important article on the thorax was written for this celebrated work, edited by Richard Bentley Todd of King's College Hospital. Todd planned the Cyclopaedia with Grant, and it was, in the words of Munk's Roll_-... . of great value in advancing the study of physiology and of comparative and microscopic anatomy. Its first number appeared in 1835, and the last in 1859". (W. Munk, Roll of the Royal College of Physicians of London, London, Royal College of Physicians, vol. 44, 1955.) Todd's biographer in the Dictionary of national biography wrote: "This cyclopaedia did more to encourage and advance the study of physiology and comparative and microscopical anatomy than any book ever published." It is known that Todd travelled abroad in order to recruit the best possible contributors for his great work. It would seem from Munk's Roll that the Cyclopaedia first appeared in numbers or parts; but existing sets are invariably found bound in four volumes with a supplement. Hutchinson's article is found in volume 4, the title-page of which is dated 1852; but it must have appeared at least before 10 August 1850, as a later publication of this date refers to it (see item No. 20a above). I would think that it appeared some time between July 1849 and June 1850: the articles first appearing separately, and then being issued together in five volumes. Hutchinson's article is of importance on several counts. First it contained the fullest account of his work with the spirometer; and second, his description of the work of the inter-costal muscles in breathing, which, he wrote: "act as a force between two movable ribs or levers". To illustrate this point he made use of some rather ingenious diagrams. His article presented a valuable account of human and animal respiration - and in many ways it can be considered a complement to the article on 'Respiration', which was written by the late Prof. John Reid, Professor of Medicine at St. Andrews. Hutchinson refers to Reid's article for the bibliography.

26. The spirometer, the stethoscope, \& scale-balance; their use in discriminating diseases of the chest, and their value in life offices: with remarks on the selection of lives for life assurance companies, London, John Churchill, 1852, pp. 79.

Notes: Hutchinson's little monograph on the spirometer, etc., written when he was Assistant-Physician to the Brompton, and Physician to the Britannia Life Office. The work contains no preface, but Hutchinson had in his 1844 paper (item No. 3 above) referred to the value of the spirometer in examining for life assurance, and he was, as the title-page tells us, personally concerned with this. The above work probably appeared late in 1852, just before Hutchinson's departure for Australia. Although published by Churchill, it is not, in my experience, a very common workeither in the older, larger medical libraries, or in commerce.

Apart from one letter to the Bendigo Advertiser (No. 27) Hutchinson's bibliography ceases at this point. It is rather curious and puzzling that after 1852, this industrious and keen observer does not appear to have published any more papers-either in Australia or in England. 


\section{A bibliography of John Hutchinson}

27. 'Fiji Islands'. Bendigo Advertiser, 5 July 1861.

Notes: The above is termed "an extract" of a letter from Hutchinson, although it was not signed by him. It was preceded by: "The following words of advice to intending emigrants to the Fiji Islands, and observations on the country and climate, are extracted from the letter of a gentleman, late well known on Bendigo, and who left this some months back for the Fijis." Following this we find twelve recommendations for intending visitors to Fiji, the first of which is: "Let every man think twice before he comes here". The others refer to the lack of employment for the white man; observations on the unhealthy atmosphere and climate; and some mention of the natives. It was dated 23 May 1861.

\section{OBITUARIES OF JOHN HUTCHINSON}

28. 'The Fiji Islands'. Bendigo Advertiser, 9 July 1861.

Notes: According to the preliminary paragraph, this letter "from an old Bendigonian" had been sent to the newspaper for publication. It begins: "My dear J.", and refers among other things to "Doctor Hutchinson, who is going to turn squatter if he can find any land in these islands suitable for sheep." It also contains some interesting references to the life in Fiji at the time. The letter was dated: Levuka, 22 April 1861.

\section{Bendigo Advertiser, 1 October 1861.}

Notes: This contained the following: "We were yesterday informed by a gentleman who had seen a letter from the Fiji Islands, that a doctor, formerly of Sandhurst, had died there of dysentery. We cannot say who is referred to, or what amount of truth there is in the rumour."

30. Bendigo Advertiser, 2 October 1861.

Notes: This contained: "Dr. Hutchinson we fear has died in the Fiji Islands of dysentery. We were unwilling to give currency to the rumour about town yesterday but it has been confirmed from so many sources that we are reluctantly compelled to believe that Dr. Hutchinson is no more."

\section{1. 'The Late John Hutchinson, M.D.' Bendigo Advertiser, 16 November 1861.}

Notes: This contained an informative account of Hutchinson and can be regarded as being the true "local" obituary. It stated that shortly after going to the Fiji Islands he was attacked by dysentery, and: "He fell into a desponding state of mind and was anxious to leave the islands and return to Victoria but there was no vessel to leave by. It is said that he became very careless of himself and fell into intemperate habitsa statement which the experience of his friends on Bendigo lead them to disbelieveand we notice it for the purpose of rescuing the character of a scientific and highly accomplished gentleman from the stigma of drunkenness. It is of course impossible to say to what state the combined effects of disappointment, disease, and the absence of all comforts in those islands may have reduced the deceased but it is due to his memory to say that those who knew him best at Sandhurst were the most astonished 


\section{P. J. Bishop}

at the report." This obituary refers to Hutchinson having died at Ovelau on $16 \mathrm{July}$, and his having been dead for several months before the news reached Sandhurst.

\section{The Times, 9 January 1862 , column 1 , Deaths.}

Notes: The above was just a notice of Hutchinson's death-no detailed obituary appeared in The Times. It read: "In July last, at Fiji, Sandwich Islands, John Hutchinson, M.D., F.R.C.S., late of Milton-street, Dorset-square, sometime Physician to the Consumptive Hospital, Brompton, and sometime Physician to the Britannia Life Assurance, city, in his 51st year."

33. [Obituary.] 'The late Dr. Hutchinson'. Medical Times and Gazette, 1862, 1: 200-201 (22 February).

Notes: Referring to Hutchinson's contributions, this journal stated: “. . . and they entitle him to be placed in the foremost rank of Physiologists of his day". It also alluded to his going out to Victoria and the Fiji Islands, and says of this: ". . . and it is believed that he had in contemplation a history of his experiences of Colonial and Savage Life". There is no other record of Hutchinson ever having undertaken such a work. Although he may well have intended writing it, his early death would, of course, account for its non-appearance. The obituary ends: ". . . the name of John Hutchinson will not sooner be extinguished than that of the great Cook, nor his kindly actions to his fellowmen sooner be forgotten."

34. [Obituary.] 'John Hutchinson, M.D.' Lancet, 1862, i: 240 (1 March).

Notes: The Lancet obituary occupied only about half a column. It does not contain as much information as the previous item-which looks as if it must have been written by someone who knew Hutchinson well-but it does contain some additional or confirmatory material.

\section{Bendigo Advertiser, 7 May 1862.}

Notes: This begins: "Dr. John Hutchinson. The following memoir of this gentleman, published in England in January last, has been kindly placed at our disposal for publication in this journal. Many of the facts contained in it had already been referred to in our brief notice of Dr. Hutchinson." In general the text of the above contains nothing that is not to be found in the Med. Times Gaz. (item No. 33 above), but the reference to a memoir published in England in January 1862, is puzzling, as the only British obituaries I have been able to trace are Nos. 33 and 34 above.

BIOGRAPHICAL ACCOUNTS OF JOHN HUTCHINSON

36. 'A pioneer in spirometry'. Lancet, 1920, ii: 563 (11 September).

Notes: One of the few accounts of Hutchinson to have appeared this century. I have been unable to discover who wrote it. It states: "After his appointment to the position of assistant physician to the Brompton Hospital he began to measure the 


\section{A bibliography of John Hutchinson}

vital capacity of the patients suffering from chest trouble, and urged the general use of the spirometer in the detection of early or threatened phthisis." However, this is not so. Hutchinson's earliest published papers, or reports of his work with the spirometer, date from 1844, and the work involved with his experiments was such that he must have begun his investigations at an earlier date. He was not appointed Assistant-Physician to the Brompton until 1850, but he had visited the hospital before this date. My authority for saying this is-The first medical report of the Hospital for Consumption ...., London, John Churchill, 1849. This most important report from the hospital, which had opened at the Manor House, Chelsea, in 1842, and later on its present site at Brompton, contained a statistical analysis of 4,358 consumptive patients: almost certainly the largest number so reported up to that time. Under the heading of symptomatology (pages 22-27) we find a report of investigations with the spirometer: "Dr. Hutchinson who has published a series of valuable observations calling the attention of the profession to the subject, kindly offered his assistance, and during several months attended at the Hospital for the purpose of testing the instrument" [my italics]. It was most probably this association with the Brompton, plus of course his growing reputation, which led to his appointment in 1850 as AssistantPhysician: a post he held for only two years. Before this, however, Hutchinson must have welcomed the opportunity of gaining access to the patients at Brompton. But his pioneer observations with the spirometer were based upon the large numbers of people he gathered from all walks of life-and not on any particular hospital population.

37. A. Hirsch, Biographisches Lexikon der hervorragenden Ärzte aller Zeiten und Völker, 2nd edition, Berlin, Urban \& Schwarzenberg, 1931, vol. 3, p. 252 (1st edition, 1886, vol. 3, pp. 327-328).

Notes: This account contains nothing that does not appear in contemporary obituaries.

38. Lew A. Hochberg, 'The capacity of the lungs as conceived by John Hutchinson a century ago.' Quarterly Bulletin of the Sea View Hospital, 1946, 8: 142-155 (April).

Notes: Until Dr. Clarke's account appeared in 1972 (item No. 39 below), this paper by Hochberg, the American thoracic surgeon and historian of thoracic surgery, was virtually the only study and description of Hutchinson's work to have been published this century. It contained long extracts from the 1846 paper and reproduced ten figures from it. See also, L. A. Hochberg, Thoracic surgery before the twentieth century, New York, Vantage Press, 1960, which included some material on Hutchinson and the spirometer.

39. Edwin Clarke, 'John Hutchinson'. In Dictionary of scientific biography, New York, Charles Scribner's Sons, 1972, vol. 6, pp. 575-576.

Notes: The most important biographical account of Hutchinson to have appeared in recent years. Referring to the spirometer Dr. Clarke states: "and his machine was the forerunner of all modern methods of estimating pulmonary function. Moreover, his research was extensive and his interpretation and application of it significant. 


\section{P. J. Bishop}

.. Hutchinson's research ... was important and influential, and affirms his place as a pioneer in the investigation of pulmonary physiology and pathology."

40. E. A. Spriggs, B. Gandevia and P. J. Bishop, 'John Hutchinson (1811-1861). Inventor of the spirometer [abstract]'. Proceedings of the Royal Society of Medicine, 1976, 69: 450.

Notes: An abstract of a communication made to a meeting of the Section of the History of Medicine (4 February 1976) by Dr. E. A. Spriggs and Mr. P. J. Bishop.

\section{SUMMARY}

This paper lists and briefly describes all known publications by and about Hutchinson that can be traced. It would appear that between 1844 and his death in 1861 Hutchinson's work had received wide dissemination, and sixteen accounts of his work with the spirometer had appeared in the British and Continental literature. In addition we have the four published accounts of his work on the intercostal muscles; his twelve very important papers on ventilation; and eight papers on other medical and allied subjects. In this century five biographical accounts of Hutchinson, or descriptions of his work have been published; but there are grounds for thinking that only in recent years has proper recognition of his achievements been made. 